\title{
Whole tumor antigen vaccination using dendritic cells: Comparison of RNA electroporation and pulsing with UV-irradiated tumor cells Fabian Benencia ${ }^{1,2,3}$, Maria C Courrèges ${ }^{1}$ and George Coukos*1,2
}

\author{
Address: ${ }^{1}$ Center for Research on Early Detection and Cure of Ovarian Cancer, University of Pennsylvania, Philadelphia, PA, USA, ${ }^{2}$ Abramson \\ Family Cancer Research Institute, University of Pennsylvania, Philadelphia, PA, USA and ${ }^{3}$ Department of Biomedical Sciences, College of \\ Osteopathic Medicine and Biomedical Engineering Program, Russ College of Engineering and Technology, University of Ohio, Athens, OH, USA \\ Email: Fabian Benencia - benencia@oucom.ohiou.edu; Maria C Courrèges - Courrege@mail.med.upenn.edu; \\ George Coukos* - gcks@mail.med.upenn.edu \\ * Corresponding author
}

Published: 29 April 2008

Journal of Translational Medicine 2008, 6:21 doi:10.1 186/1479-5876-6-21
Received: 15 January 2008

Accepted: 29 April 2008

This article is available from: http://www.translational-medicine.com/content/6/1/2I

(C) 2008 Benencia et al; licensee BioMed Central Ltd.

This is an Open Access article distributed under the terms of the Creative Commons Attribution License (http://creativecommons.org/licenses/by/2.0), which permits unrestricted use, distribution, and reproduction in any medium, provided the original work is properly cited.

\begin{abstract}
Because of the lack of full characterization of tumor associated antigens for solid tumors, whole antigen use is a convenient approach to tumor vaccination. Tumor RNA and apoptotic tumor cells have been used as a source of whole tumor antigen to prepare dendritic cell (DC) based tumor vaccines, but their efficacy has not been directly compared. Here we compare directly RNA electroporation and pulsing of DCs with whole tumor cells killed by ultraviolet (UV) B radiation using a convenient tumor model expressing human papilloma virus (HPV) E6 and E7 oncogenes. Although both approaches led to DCs presenting tumor antigen, electroporation with tumor cell total RNA induced a significantly higher frequency of tumor-reactive IFN-gamma secreting $T$ cells, and E7-specific CD8+ lymphocytes compared to pulsing with UV-irradiated tumor cells. DCs electroporated with tumor cell RNA induced a larger tumor infiltration by $T$ cells and produced a significantly stronger delay in tumor growth compared to DCs pulsed with UV-irradiated tumor cells. We conclude that electroporation with whole tumor cell RNA and pulsing with UV-irradiated tumor cells are both effective in eliciting antitumor immune response, but RNA electroporation results in more potent tumor vaccination under the examined experimental conditions.
\end{abstract}

\section{Introduction}

Because tumor-associated antigens are not well characterized for the majority of human tumors, polyvalent vaccines prepared with whole tumor antigen are an attractive approach to induce tumor vaccination [1,2]. Recent advances in generation and manipulation of DCs provide opportunities to design powerful tumor vaccines. DCs are ideal vehicles for polyvalent tumor vaccination, as they readily process and present tumor antigen taken up from dying tumor cells.
DCs pulsed with apoptotic tumor cells have been used successfully to induce tumor vaccination [3-6,6-12]. Although controversy surrounds the ability of necrotic versus apoptotic tumor cells to serve as a source of multivalent antigen to pulse DCs [10,13-15], UVB irradiation has been shown to result in a mixed population of apoptotic and necrotic tumor cells [16]. Tumor cells exposed to lethal ultraviolet-B (UVB) radiation have been shown to provide a suitable source of tumor antigen for DCs $[16,17]$. For example, UV-irradiated primary tumor cells provide sufficient tumor antigen to elicit expansion of tumor-reactive autologous $\mathrm{T}$ cells ex vivo in patients with 
advanced ovarian cancer [17], suggesting that this approach can be used clinically to induce therapeutic vaccination.

Several reports have described the use of tumor-extracted RNA as source of tumor antigen for the preparation of DCs and have indicated its potential use for antigen-specific or polyvalent tumor vaccination in the absence of identified tumor antigens [18-23]. Such approach may address important limitations in the procurement of tumor antigen, as primary tumor cell cultures are not feasible for a large number of patients. Although the feasibility and efficacy of electroporation of DCs with RNA for the preparation of polyvalent tumor vaccines has been convincingly demonstrated, a direct comparison of DC vaccines prepared with tumor RNA versus dying whole tumor cells has not been performed.

In this study, we compared tumor RNA to apoptotic tumor cells as a source of tumor antigen to generate a DCbased vaccine against tumors expressing the early gene products E6 and E7 of the human papilloma virus (HPV). We report that the use of tumor RNA as a source of tumor antigen is valuable alternative and superior to UV-irradiated tumor cells.

\section{Materials and methods Cell lines}

TC-1, cell line was a generous gift from Dr. Yvonne Paterson, University of Pennsylvania. TC-1 cells were maintained in RPMI (Invitrogen, Carlsbad, CA) supplemented with L-glutamine $(2 \mathrm{mM})$; penicillin $(100 \mathrm{U} / \mathrm{ml})$; streptomycin $(100 \mu \mathrm{g} / \mathrm{ml}) ; 10 \%$ fetal bovine serum (FBS), and geneticin $(1 \mathrm{mg} / \mathrm{ml})$.

ID8, a cell line derived from spontaneous in vitro malignant transformation of $\mathrm{C} 57 \mathrm{BL} / 6$ mouse ovarian surface epithelial cells, was a generous gift from Dr. Paul F. Terranova, University of Kansas [24]. ID8 cells were maintained in DMEM medium (Invitrogen) supplemented with $4 \%$ FBS, penicillin, streptomycin, insulin $(5 \mu \mathrm{g} / \mathrm{ml})$, transferrin $(5 \mu \mathrm{g} / \mathrm{ml})$, and sodium selenite $(5 \mathrm{ng} / \mathrm{ml}$, all Roche, Indianapolis, IN) in a $5 \% \mathrm{CO}_{2}$ atmosphere at $37^{\circ} \mathrm{C}$. An ID8 cell line expressing the HPV16 E6 and E7 antigens was generated by transducing ID8 cells with the retroviral vector LXSN16E6E7 (American Type Culture Collection, Rockville, MD, donated by Dr. D. Galloway), which encodes the HPV16 E6 and E7 genes, as well as the neomycin phosphotransferase gene. The PA317 cell line was used to generate the retroviral vectors as previously described [25]. Selection of ID8 cells transduced with E6 and E7 (ID8-E6/7) or ID8 cells transduced with a control retroviral vector (LXSN) was achieved under neomycin pressure (1 $\mathrm{mg} / \mathrm{ml})$ [25]. The murine L929 (ATCC) immortalized cell line was grown in RPMI 1640 with $10 \%$
FBS and penicillin/streptomycin. All lines tested negative for Mycoplasma by PCR.

\section{Animals and tumors}

Six to eight week old female C57BL/6 (H-2Kb) and BALB/ c $\left(\mathrm{H}-2 \mathrm{~K}^{\mathrm{d}}\right)$ mice (Charles River Laboratories, Wilmington, MA) were used in protocols approved by the Institutional Animal Care and Use Committee and the University of Pennsylvania. TC-1 tumors were generated in C57BL/6 mice by s.c. inoculation of $2 \times 10^{4} \mathrm{TC}-1$ cells in $0.2 \mathrm{ml}$ of PBS. Tumors were detectable ten days later and were measured weekly using a Vernier caliper. Tumor volumes were calculated by the formula $\mathrm{V}=1 / 2 \mathrm{~L} \times \mathrm{W}^{2}$, where $\mathrm{L}$ is length (longest dimension) and $\mathrm{W}$ is width (shortest dimension). For some in vivo studies, $\mathrm{CD}^{+}$cells were depleted with rat anti-mouse CD8 (MCA1768XZ) and CD4+ cells with rat anti-mouse CD4 (MCA1767XZ) (both Serotec, Raleigh, NC). The antibodies were administered intravenously ( $100 \mu \mathrm{g} / \mathrm{animal})$ on the day of tumor injection and a second dose one week later.

\section{Generation of bone marrow-derived DCs}

Murine dendritic cells were generated from bone marrow precursor cells with recombinant murine granulocytemacrophage colony-stimulating factor (GM-CSF; Peprotech, Rocky Hill, NJ; $20 \mathrm{ng} / \mathrm{ml}$ ) as described previously [26]. Cells were counted using Trypan blue. Differentiation into immature DCs was documented through flow cytometry detection of CD80, CD86 and major histocompatibility complex class II (MHC-II). DC maturation was induced by culturing cells in RPMI media under standard conditions in the presence of $10 \mathrm{ng} / \mathrm{ml}$ murine GM-CSF supplemented with $0.1 \mu \mathrm{g} / \mathrm{ml}$ lipopolysaccharide (LPS, Sigma Chemical Co, Saint Louis, MO) and $20 \mathrm{ng} / \mathrm{ml}$ tumor necrosis factor-alpha (TNF- $\alpha$, Peprotech).

\section{DC electroporation with tumor RNA}

Total cellular RNA was extracted from TC-1 cells using TRIzol Reagent (Invitrogen). Cells grown in $75 \mathrm{~cm}^{2}$ flasks were resuspended and lysed using TRIzol reagent. Chloroform ( $0.2 \mathrm{ml}$ per $\mathrm{ml}$ of TRIzol reagent) was added and incubated at room temperature for $2 \mathrm{~min}$. The samples were centrifuged at $12,000 \times \mathrm{g}$ for $15 \mathrm{~min}$ at $4^{\circ} \mathrm{C}$, and the aqueous phase was transferred to a new tube. Cold isopropanol was added at $0.5 \mathrm{ml}$ per $\mathrm{ml}$ TRIzol reagent to precipitate RNA. Following $10 \mathrm{~min}$ incubation at room temperature the samples were centrifuged at $12,000 \times \mathrm{g}$ for $10 \mathrm{~min}$ at $4^{\circ} \mathrm{C}$. The RNA pellet was washed once with $70 \%$ DEPC-ethanol and centrifuged at $7500 \times \mathrm{g}$ for $5 \mathrm{~min}$. The pellet was briefly dried and dissolved in DEPC water. The quality and quantity of the total RNA was checked using RNA Nano LabChip ${ }^{\circledR}$ (Agilent Technologies, Palo Alto, CA) according to the protocol provided. Two million DCs were resuspended with the appropriate amount of total TC-1 RNA in a $0.2-\mathrm{cm}$ cuvette and electroporated 
using Gene Pulser II (BIO-RAD Laboratories, Hercules, CA) under different voltage and capacitance settings. DCs electroporated in the absence of TC-1 RNA (mock) were used as controls for some experiments.

\section{DC pulsing with apoptotic tumor cells}

Subconfluent cultures of TC-1 cells were rinsed twice in phosphate buffer saline (PBS) and exposed to ultravioletB (UVB) radiation at various doses up to $1500 \mu \mathrm{W} / \mathrm{cm}^{2}$ for various times. Apoptosis at 24 hours was quantified by flow cytometry detection of annexin-V staining using the TACS $^{\mathrm{rm}}$ Annexin-Biotin Apoptosis detection kit (R\&D Systems, Minneapolis, MN) and confirmed with the ApopTag peroxidase in situ detection kit (Intergen, Purchase, NY) and the Apoptotic DNA-Ladder Kit (Roche), according to the manufacturers' instructions. Twenty-four hours after UVB radiation tumor cells were incubated with immature DCs at a 2:1 ratio (tumor cells, DCs). Twenty-four hours later, TNF- $\alpha$ (Peprotech; $20 \mathrm{ng} / \mathrm{ml}$ ) and LPS $(0.1 \mu \mathrm{g} / \mathrm{ml})$ were added for additional 48 hours. DCs were harvested, rinsed and counted by trypan blue exclusion. In some experiments, radiated tumor cells were labeled with PKH26 fluorescent dye (Sigma; $5 \mu \mathrm{M}$ ) for $5 \mathrm{~min}$ at room temperature. RPMI supplemented with $10 \%$ FBS was added to stop the reaction and cells were rinsed three times prior to using them for pulsing DCs.

\section{Animal vaccination}

Animals received one intraperitoneally (i.p.) and then twice subcutaneously (s.c.) seven days apart, DCs $\left(5 \times 10^{5}\right.$ per dose) electroporated with TC-1 RNA or loaded with TC- 1 cells killed by UVB and incubated with TNF- $\alpha$ (20 $\mathrm{ng} / \mathrm{ml})$ and LPS $(0.1 \mu \mathrm{g} / \mathrm{ml})$ were injected once. DCs. Control animals were injected with DCs mock electroporated and matured with TNF- $\alpha$ and LPS. Animals were challenged with tumor cells seven days after the last DC vaccination.

\section{Flow cytometry}

Cells were subjected to four-color flow cytometry on a FACSCalibur flow cytometer using CellQuest 3.2.1f1 software (Becton Dickinson, San Jose, CA). Non-specific staining was blocked with anti-CD16/CD32 antibody (FC block, 2.4G2; BD Pharmingen; San Diego, CA). Fluorochrome-conjugated monoclonal antibodies against CD3 (17A2), CD8 [53-67], CD11c (HL3), CD80 (16-10A1), CD86 (GL1), MHC-I (H-2 kb/H-2Db), MHC-II (KH74; all BD Pharmingen, San Diego, CA) were used at 1:100 dilution. PE-conjugated H2-Db RAHYNIVTF tetramer recognizing a dominant MHC-I epitope of E7 antigen [27] was a kind gift of Dr. Yvonne Paterson. Rabbit anti-HPV-16 E6 $(\mathrm{N}-17)$ and E7 (ED-17) antibodies (Santa Cruz Biotechnology, Santa Cruz, CA) were used at 1:100 dilution.

\section{Proliferation assays}

For mixed leukocyte reactions C57BL/6 DCs were electroporated with TC- 1 RNA ( $\left.50 \mu \mathrm{g} / 10^{6} \mathrm{DCs}\right)$ or loaded with TC- 1 cells killed with UVB; incubated with TNF- $\alpha$ and LPS for $48 \mathrm{~h}$; washed twice with PBS; and subjected to gammairradiation (20 Gy). DCs were seeded in 96-well roundbottom plates at various dilutions in RPMI containing $10 \%$ FBS. BALB/c spleen lymphocytes were procured as described [28]. Constant number of BALB/c lymphocytes $\left(1 \times 10^{5}\right.$ cells/well $)$ were incubated with irradiated C57BL/ 6 DCs at increasing ratios (DC: lymphocytes) for 5 days at $37^{\circ} \mathrm{C}$. $\left[{ }^{3} \mathrm{H}\right]$ thymidine (NEN Life Science, Boston, MA, 1 $\mu \mathrm{Ci}$ /well) was added for 18 hours at $37^{\circ} \mathrm{C}$. Samples were recovered on glass fiber filters and analyzed with a Microbeta Trilux (Perkin Elmer Wallac, Inc., Gaithersburg, $\mathrm{MD})$. Each experimental value was determined three times. For some experiments, splenocytes from vaccinated animals were cultured with gamma-irradiated (20 Gy) tumor cells in the presence of $20 \mathrm{U} / \mathrm{ml}$ of recombinant murine IL-2 (Peprotech). After 5 days $1 \mu \mathrm{Ci} /$ well of $\left[{ }^{3} \mathrm{H}\right]$ thymidine was added for 18 hours at $37^{\circ} \mathrm{C}$.

\section{Chemotaxis assay}

Migration of DCs towards murine macrophage inflammatory protein (MIP)-3 $\alpha$ or MIP-3 $\beta$ (R\&D Systems, Minneapolis, MN) was assessed in 96-well chemotaxis chambers using an $8 \mu \mathrm{m}$-pore nitrocellulose membrane (Neuroprobe, Gathersburg, MD) [29]. Pyrogen-free RPMI 1640 containing $1 \%$ BSA was used as chemotactic media. Results are presented as chemotactic index (CI), defined as fold increase in cell migration in the presence of chemotactic factors compared to chemotactic media alone. Each experiment was performed in triplicate.

\section{IFN- $\gamma$ ELISPOT}

ELISPOT was performed as previously described [28]. We used purified anti-mouse IFN- $\gamma$ (R4-6A2) for capture and biotin anti-mouse IFN- $\gamma$ (XMG1.2) (both BD Pharmingen) for detection.

\section{Immunostaining}

Solid tumor samples ( $\mathrm{n}=6$ for each experimental group) were snap-frozen in ornithine carbamyltransferase (OCT, Tissue Tek, Sakura, Torrance, CA). For immunofluorescense analysis, sections were fixed in cold acetone for 10 minutes and sequentially incubated with anti-mouse CD16/32 antibody (1:100 dilution), FITC-anti-mouse CD3 (17A2) and biotin-anti-mouse CD8 (53-67, 1:100 dilution, both BD Pharmingen). After incubation with streptavidin tetramethylrhodamine conjugate (Molecular Probes, Eugene, OR) (1:200 dilution), sections were counterstained with 4',6'-diamidino-2-phenylindole hydrochloride (DAPI) and inspected under the fluorescent microscope. 
For immunofluorescense of DCs following electroporation with TC-1 RNA, electroporated DCs were seeded on glass coverslips and cultured in RPMI in the presence of $10 \% \mathrm{FBS}$ and $10 \mathrm{ng} / \mathrm{ml} \mathrm{GM}$-CSF for two days. Cells were fixed with acetone and consecutively stained with antiHPV-16 E7 antibody (ED-17, Santa Cruz Biotechnologies) and anti-rabbit FITC (BD Pharmingen). Slides were counterstained with DAPI. Images were acquired through Cool SNAP Pro color digital camera (Media Cybernetics, Carlsbad, CA). Ten different fields for each sample at $\times$ 400 magnification were evaluated for cell counting.

\section{Immunoprecipitation and Western blot}

For E7 immunoprecipitation and Western blot analysis, ID8-E6/7 and ID8 control cells were lysed in M-Per mammalian protein extraction kit (Pierce, Rockford, IL) plus protease inhibitor cocktail (HALT Protease inhibitor kit, Pierce). Lysate concentration was determined by the Bradford assay (Biorad; Hercules, CA). Two hundred micrograms of extract was subjected to immunoprecipitation with rabbit anti-HPV16 E7 (ED-17, Santa Cruz Biotechnologies). Immunoconjugates were collected on protein A-agarose (Invitrogen), washed with lysis buffer, and resolved on $15 \%$ acrylamide gels. Proteins were transferred to polyvinylidene difluoride membranes (Immobilon-P, Millipore) and probed with mouse anti-E7 antibody (clone 8C9, Zymed Labs Inc., San Fransisco, CA). Sheep anti-mouse IgG-HRP (NA93IV, Amersham Biosciences, Buckinhamshire, UK) was used as the secondary reagent. Proteins were visualized by enhanced chemiluminescence (Lumigen PS-3, Amersham) and exposure to Kodak X-Omat Blue film.

\section{RT-PCR and Real-Time Quantitative Reverse Transcription-PCR}

The expression of E6 and E7 was demonstrated using RTPCR with the following primers: E6 forward primer (F), 5'-AAA GCA GAC ATT TTA TGC ACC A-3'; E6 reverse primer (R), 5'-TCA TGC AAT GTA GGT GTA TCT CC -3'; E7 F 5'-CAC GTA GAG AAA CCC AGC TGT A -3'; E7 R 5'GTA CCC TCT TCC CCA TTG TT-3'. The RT portion of the RT-PCR was conducted using SuperScript reverse transcriptase (Invitrogen) at $50^{\circ} \mathrm{C}(10 \mathrm{~min})$. The PCR cycling was conducted with Taq polymerase for both sequences at $94^{\circ} \mathrm{C}(3 \mathrm{~min}), 50^{\circ} \mathrm{C}(1 \mathrm{~min})$, and $72^{\circ} \mathrm{C}(1 \mathrm{~min})$ for 40 cycles.

The AbiPrism 7700 Sequence Detection System and SYBR green I PCR kits (both Applied Biosystems, Foster City, CA) were used for Real-Time PCR as described previously [30]. The following primers were used: E6: F 5'-GAC TTT GCT TTT CGG GAT TTA TGC -3', R 5'-TCA CAC AAC GGT TTG TTG TAT TGC-3'; E7: F 5'-CTG GAC AAG CAG AAC CGG ACA-3', R 5'-TGC TTT GTA CGC ACA CCG AA-3'. We normalized the cDNA load to mouse glyceraldehyde- 3-phosphate dehydrogenase (GAPDH) with primers GAPDH F 5'-CCT GCA CCA CCA ACT GCT TA-3' and GAPDH R 5'-CAT GAG TCC TTC CAC GAT ACC A-3'. Data were expressed as relative units to GAPDH mRNA molecules. Molecules were considered to be present if more than five copies of mRNA were detected for every $10^{6} \mathrm{cop}-$ ies of GAPDH mRNA.

\section{Statistical analysis}

A two-tailed Student's t-test was applied to determine differences between two groups. For multiple comparisons we performed ANOVA with post-analysis comparisons by the Tukey-Kramer multiple comparisons test. Non-parametric studies were performed by using the Mann-Whitney $U$ test. A value of $\mathrm{p}<0.05$ was considered significant. Data are expressed as mean $\pm \mathrm{SD}$. Data was analyzed using Graph Pad Instat software (GraphPad Software, Inc., San Diego, CA).

\section{Results \\ Preparation of DCs electroporated with TC-I cell RNA (RNA-DCs)}

To test the efficacy of loading DCs with tumor antigen by RNA electroporation we used TC-1 cells, a mouse adenocarcinoma cell line generated by cotransfection of lung epithelial cells with HPV-16 E6 and E7 genes and H-Ras [31], which has been used to test E6 and E7-targeted tumor immunotherapy [32-34]. Reproducible amounts of total RNA ranging between $20-35 \mu \mathrm{g}$ RNA $/ 10^{6}$ cells were obtained from cultured TC- 1 cells (Mean $=27.05, \mathrm{SD}=$ 9.183, $\mathrm{N}=10$ independent samples). High quality RNA was procured (Figure 1A), with rRNA ratio (28S/18S) reproducibly greater than 2.00 (Figure $1 \mathrm{~B}$ ).

To determine the best conditions for RNA electroporation in our system, bone marrow-derived DCs were electroporated with tumor cell RNA using different capacitance and voltage settings and $25 \mu \mathrm{g}$ RNA per $10^{6} \mathrm{DCs}$, which represents RNA from approximately one tumor cell per DC. The reaction was performed in a total volume of $200 \mu \mathrm{L}$. As shown in Figure 1C, the highest expression of E7 antigen in live electroporated DCs, was obtained at $300 \mathrm{~V}$ and $150 \mu \mathrm{F}$. These settings yielded 50\% viability in electroporated DCs, as determined by flow cytometry PI exclusion analysis (Figure 1D). Similar viability levels were obtained in DCs electroporated in the absence of RNA (mock, not shown).

To optimize DC electroporation, we electroporated DCs with different amounts of TC-1 RNA (5-50 $\mu \mathrm{g} / 10^{6}$ DCs) using the previously determined settings ( $300 \mathrm{~V}, 150 \mu \mathrm{F})$. E6-transcripts are longer than E7. As shown in Figure 1E, high E6 expression was observed only after electroporating $50 \mu \mathrm{g}$ TC- 1 RNA $/ 10^{6}$ DCs. Higher RNA amounts did not result in increased E6 expression (not shown). Elec- 
A

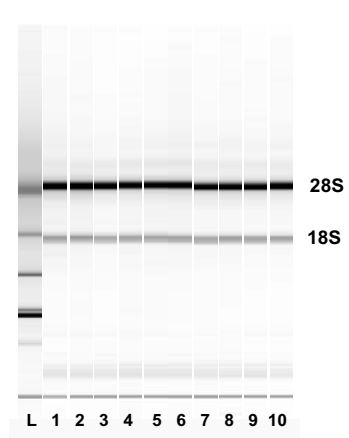

C

TC-1 RNA
B

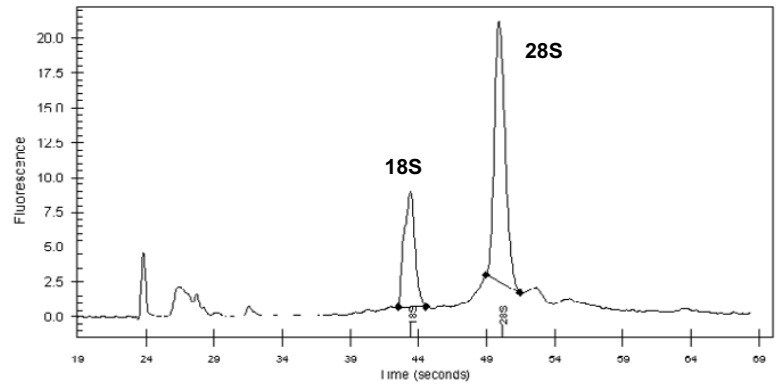

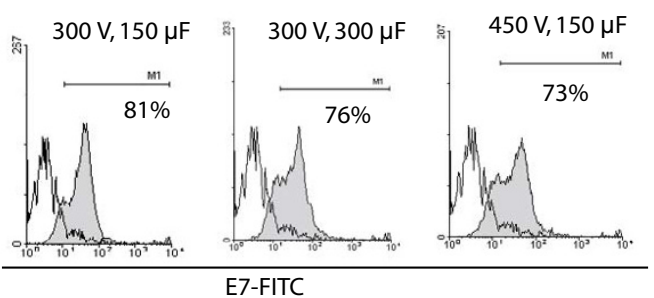

E

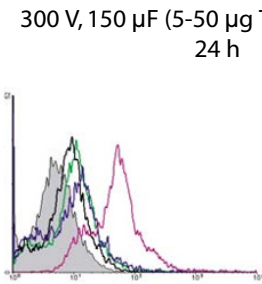

E6-FITC

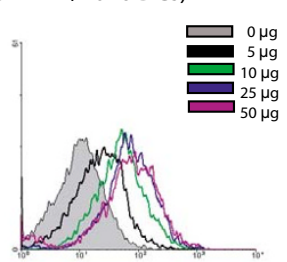

E7-FITC
D
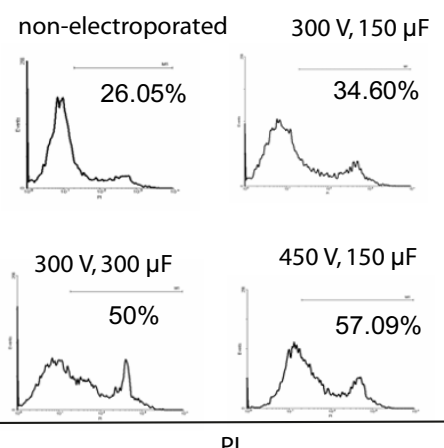

$\mathbf{F}$

$300 \mathrm{~V}, 150 \mu \mathrm{F}(50 \mu \mathrm{g} \mathrm{TC}-1$ RNA/10E6 DCs) 4 days

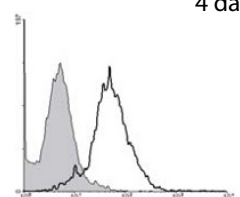

E6-FITC

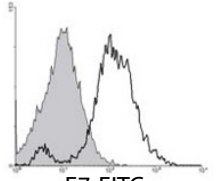

E7-FITC

G

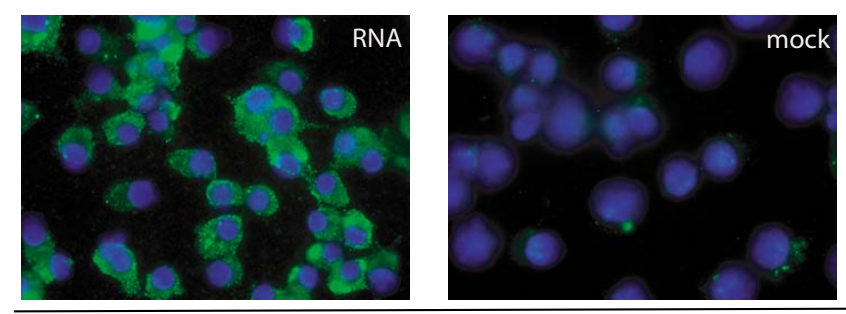

E7-FITC

\section{Figure I}

Expression of tumor-associated HPV E6 and E7 antigens by bone marrow-derived DCs after RNA electroporation. (A) Gellike image obtained from 10 independent samples of TC-I RNA analyzed by the Agilent bioanalyzer. (B) Electropherogram of sample I from A showing ribosomal RNA peaks. (C) Flow cytometry analysis of intracellular E7 expression in CDI I c ${ }^{+}$cells 24 hours after electroporation with TC-I RNA at different voltage and capacitance conditions. Electroporation was performed with $25 \mu \mathrm{g}$ TC-I RNA/106 DCs (grey): mock electroporated (white). (D) Flow cytometry analysis of DC viability 24 hours after electroporation at different conditions of voltage and capacitance. Electroporation was performed with $25 \mu \mathrm{g}$ TC-I RNA/I06 DCs. X-axis reflects propidium iodide (PI) staining. (E) Flow cytometry analysis of intracellular E6 and E7 expression in CDI I ${ }^{+}$ cells 24 hours after electroporation with different amounts of TC-I RNA at 300V and I50 $\mu$ F. The experiment was repeated two times with similar results. (F) Flow cytometry analysis of intracellular E6 and E7 expression in CDI I c cells 4 days after electroporation with $50 \mu \mathrm{g}$ of TC-I RNA/I $0^{6} \mathrm{DCs}$ at $300 \mathrm{~V}$ and I50 $\mu \mathrm{F}$. RNA electroporated (white); mock electroporated (grey). (G) Immunofluorescence of DCs stained with anti-HPV E7 antibody 24 hours after electroporation with TC- I cell RNA or mock electroporated. Cells were counterstained with DAPI. 200X magnification. All experiments were repeated twice with similar results. 
troporation with $50 \mu \mathrm{g}$ RNA $/ 10^{6}$ DCs also ensured high expression of E7-antigen in DCs (Figure 1E). As shown in Figure 1F, high expression of E6 and E7 protein was detectable by flow cytometry for at least 4 days after RNA electroporation with $50 \mu \mathrm{g}$ of TC- 1 RNA/10 ${ }^{6}$ DCs. Immunofluorescence staining confirmed the presence of E7 protein in the cytoplasm of DCs 24 hours after electroporation with $50 \mu \mathrm{g}$ TC- $1 \mathrm{RNA} / 10^{6} \mathrm{DCs}$ (Figure $1 \mathrm{G}$ ).

\section{Preparation of DCs pulsed with UV irradiated TC-I cells (UV-DCs)}

We tested various doses of ultraviolet-B (UVB) light and exposure times to identify UVB conditions that kill greater than $95 \%$ of TC-1 cells (not shown). Irradiation with $1500 \mu \mathrm{W} / \mathrm{cm}^{2} \mathrm{UVB}$ for $10 \mathrm{~min}$ induced apoptosis in TC-1 cells as assessed by DNA fragmentation detectable by TUNEL assay (Figure 2A) and DNA laddering (Figure 2B), while by flow cytometry the majority of cells were annexin- $\mathrm{V}$ positive or propidium iodide and annexin- $\mathrm{V}$ double positive within 24 hours (Figure 2C).

To verify the uptake of UV-irradiated cells by DCs, UVirradiated TC-1 cells were labeled with PKH26 fluorescent dye prior to pulsing of DCs. DCs and UV-irradiated tumor cells were cocultured for 18 hours to allow the uptake of tumor cell material by DCs. Cells were then stained with antibody against CD11c, and CD11 $\mathrm{c}^{+}$DCs were analyzed for PKH26 expression with flow cytometry. More than $60 \%$ of DCs had taken up fluorescent tumor cells (Figure 2D), compared with a background level of $1 \%$ in the control sample containing DCs and UV-irradiated cells admixed just before analysis (not shown).

\section{Maturation of RNA-DCs and UV-DCs}

We assessed whether DCs prepared by RNA electroporation or pulsing with UV-irradiated tumor cells respond differently to maturation stimuli such as TNF- $\alpha$ and LPS. Significant surface expression of CD86 and CD80 and MHC-II molecules was noted in DCs 48 hours post-electroporation with tumor cell RNA, as described above, in the presence of TNF- $\alpha$ and LPS (Figure 3A). Similarly, immature DCs incubated with TC- 1 cells exposed 24 hour earlier to lethal dose of UVB radiation upregulated CD80, CD86 and MHC-II 48 hours post-phagocytosis, in the presence of TNF- $\alpha$ and LPS (Figure 3B).

Next, we assessed whether DCs electroporated with tumor cell RNA (RNA-DCs) or pulsed with UV-irradiated tumor
A

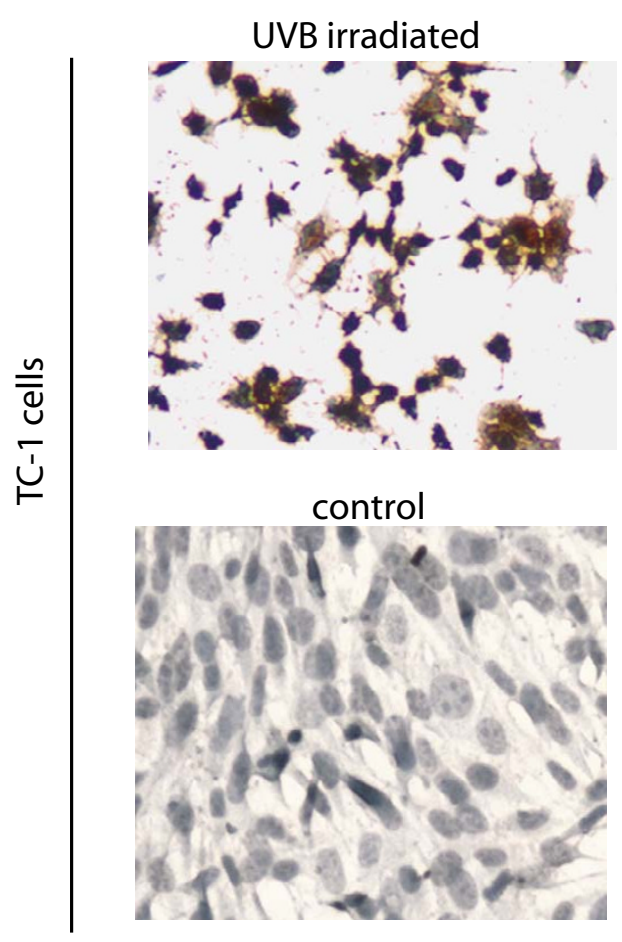

B

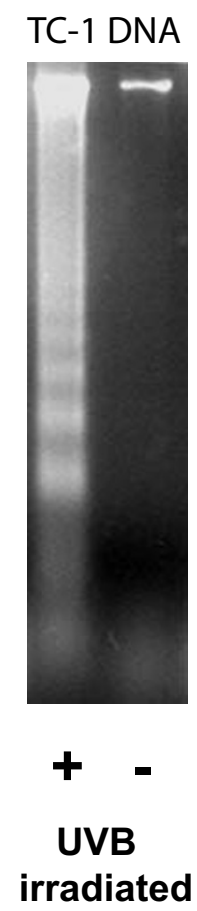

C UVB irradiated TC-1 cells

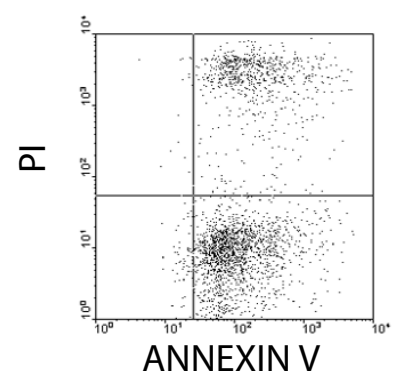

D

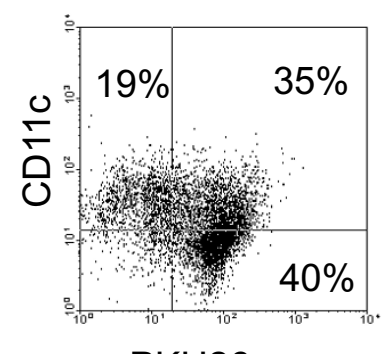

PKH26

Figure 2

UVB-induced apoptosis of TC-I cells and maturation of TC-I antigen-loaded DCs. (A) TUNEL assay of UVB-treated and control TC-I cells 24 hours post-irradiation. (B) DNA ladder assay of TC-I cells 24 hours after irradiation with UVB light. (C) Flow cytometry analysis of annexin V in UVB-treated cells 24 hours post-irradiation. (D) Percentage of DCs that have engulfed tumor cells, as determined by flow cytometry. DCs were pulsed with cells killed by UVB. Apoptotic tumor cells were labeled with PKH26 prior to pulsing. DCs were stained with antibody against CDI Ic. 
A

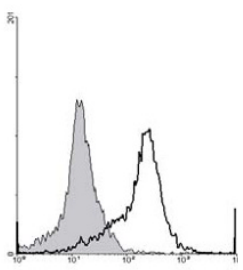

CD86

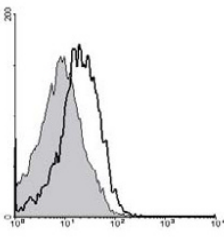

CD80

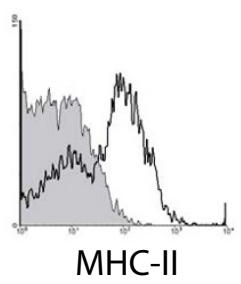

MHC-II
C

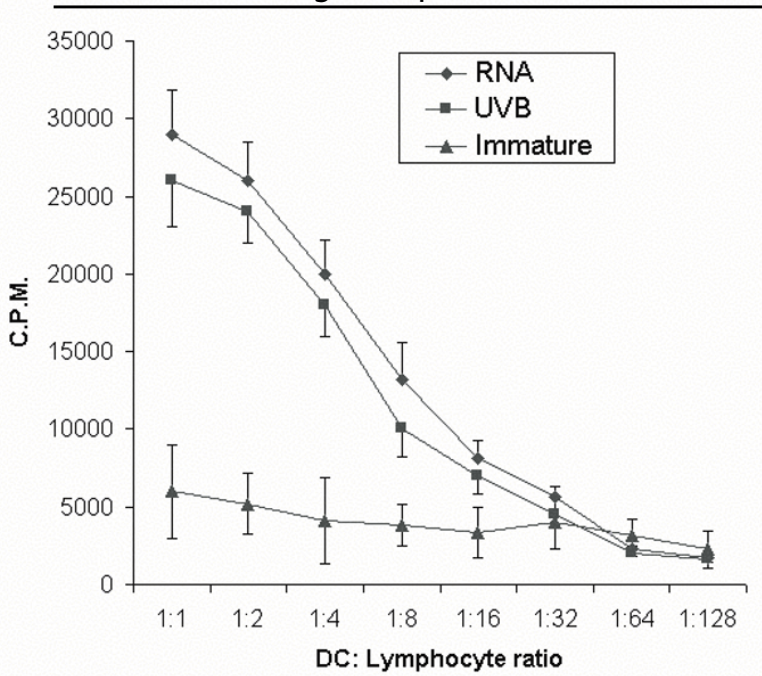

B

UVB

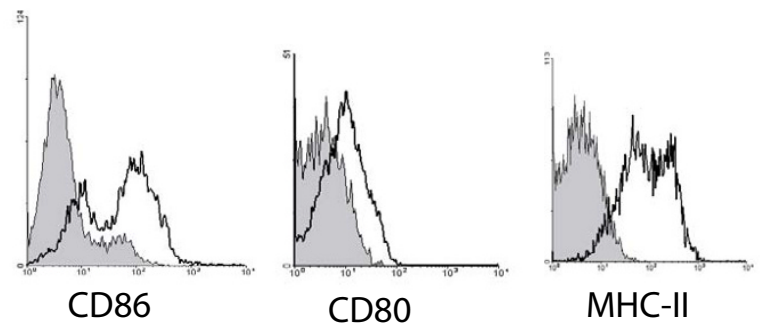

D

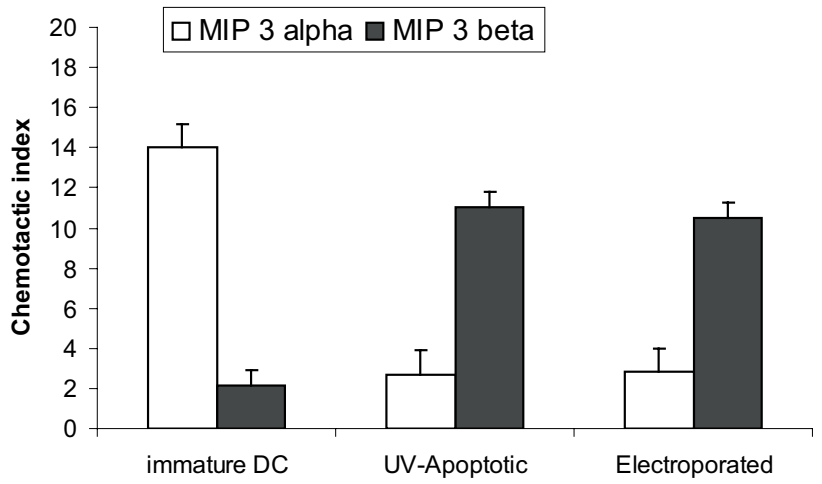

Figure 3

(A) Expression of maturation markers in $\mathrm{E}^{+} \mathrm{CD} / \mathrm{lc} \mathrm{c}^{+}$gated cells 72 hours after electroporation with TC-I RNA (50 $\mu \mathrm{g} / \mathrm{I} 0^{6}$ cells). LPS and TNF- $\alpha$ were added to the culture medium 24 hours after electroporation. (white): specific antibody; (grey): isotype control. The experiment was repeated two times with similar results. (B) Expression of markers in CDI I c ${ }^{+}$gated cells 72 hours after phagocytosis of UVB-irradiated TC-I cells. LPS and TNF- $\alpha$ were added to the culture medium after 24 hours of coincubation. (white): specific antibody; (grey): isotype control. (C) Proliferation of allogeneic BALB/c splenocytes induced by C57BL/6 DCs electroporated with TC-I cell RNA (RNA) or pulsed with UV-irradiated TC-I cells (UVB). DCs were treated with TNF- $\alpha$ and LPS. Data were obtained 48 hours after stimulation of splenocytes and are expressed as the mean \pm SEM of two experiments with triplicate observations per experiment. (D) Migration of DCs towards MIP-3 $\alpha$ or MIP-3 372 hours after electroporation with TC-I RNA (RNA) or pulsing with UV-irradiated TC-I cells (UVB). LPS and TNF- $\alpha$ were added to the culture medium after 24 hours of coincubation. Chemotactic index is defined as the fold increase in cell migration caused by the chemotactic factors. Data are expressed as the mean \pm SD of two experiments with quadruplicate observations per experiment.

cells (UV-DCs) and matured with TNF- $\alpha$ and LPS differ in vitro in their ability to induce proliferation of allogeneic lymphocytes or to migrate towards lymphoid organ chemokines. Immature DCs were incubated for 48 with TC-1 cells exposed 24 hours earlier to lethal UVB radiation or were electroporated with tumor cell RNA, as described above. To minimize differences in the amount of original tumor antigen used with both loading proce- dures, DCs were incubated with UVB-irradiated cells at 1:2 ratio (DC, tumor cells) or electroporated with an equivalent amount of total RNA (50 $\mu$ g RNA corresponding to $2 \times 10^{6}$ tumor cells per $10^{6} \mathrm{DCs}$ ). RNA-DCs stimulated proliferation of allogeneic spleen lymphocytes in a similar manner to UV-DCs. As expected, unpulsed immature DCs did not stimulate allogeneic reaction (Figure 3C). 
A switch in chemokine receptors is a hallmark of DC maturation. Among others, this entails upregulation of CCR7 and downregulation of CCR6 [35]. RNA-DCs and UVDCs matured with TNF- $\alpha$ and LPS exhibited similar migratory properties. As shown in Figure 3D, both DCs lost the ability to migrate towards macrophage inflammatory protein 3-alpha (MIP3- $\alpha$ ), the ligand for CCR6, and acquired the ability to migrate towards MIP-3 $\beta$, the ligand for CCR7.

A
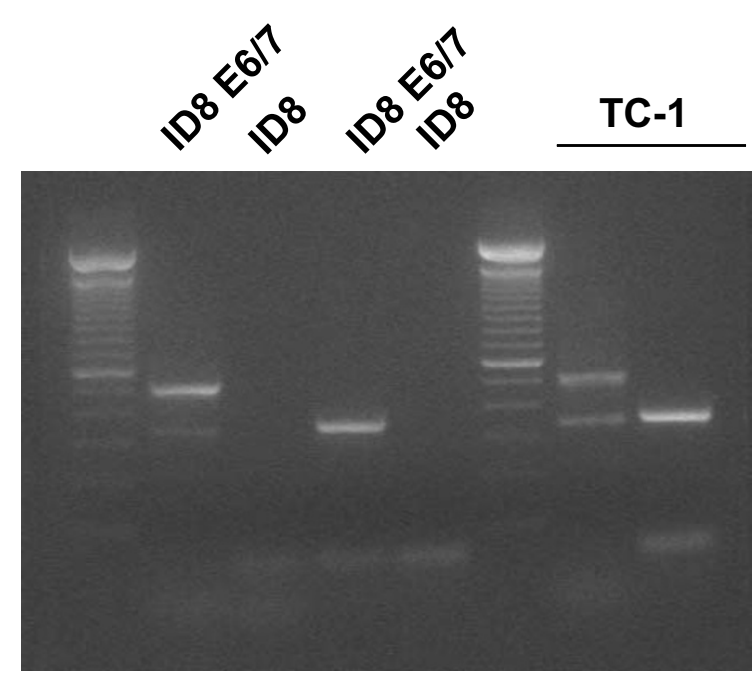

$\begin{array}{llllllll}M & E 6 & E 6 & \text { E7 } & \text { E7 } & \text { M } & \text { E6 } & \text { E7 }\end{array}$

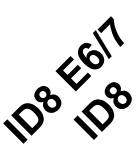

B

\section{Development of additional tumor targets expressing HPV- 16 E6 and E7}

To further compare tumor vaccination with RNA-DCs and UV-DCs, we engineered an additional tumor cell line expressing HPV E6 and E7. We used the syngeneic C57BL/ 6 murine ovarian cancer cell line ID8. ID8 cells transduced with the retroviral vector LXSN16E6E7, which encodes the HPV16 E6 and E7 genes, as well as the neomycin phosphotransferase gene (ID8-E6/7) stably expressed E6 and E7 mRNAs under genetecin pressure,

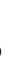

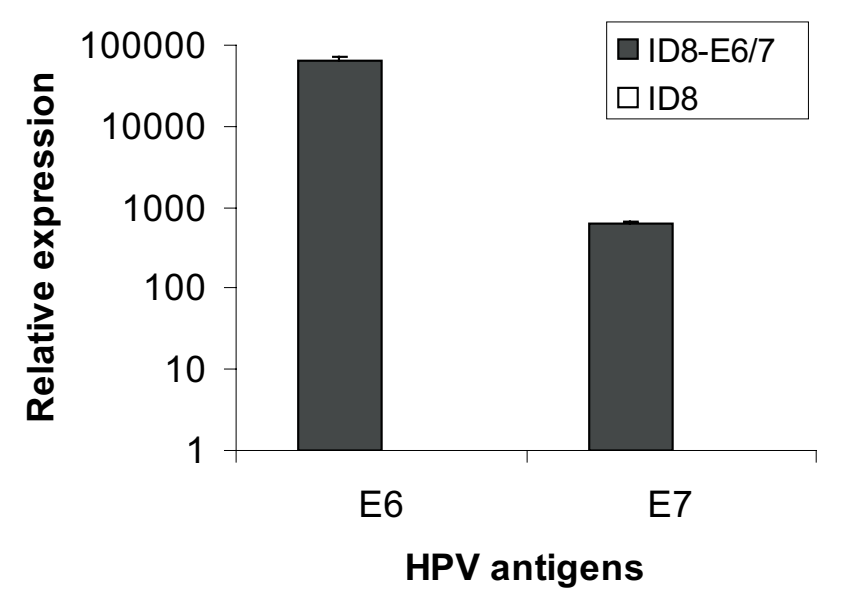

C

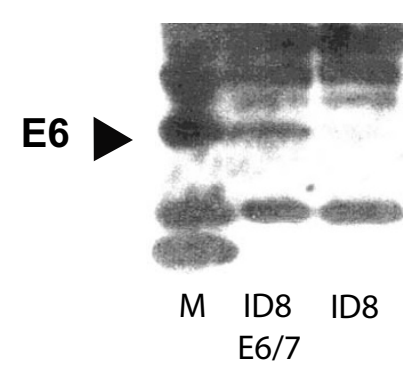

D

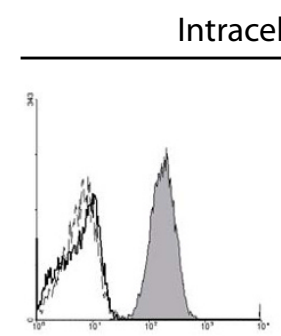

E6-FITC

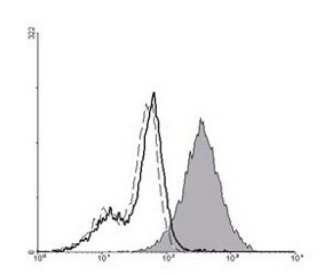

E7-FITC
E

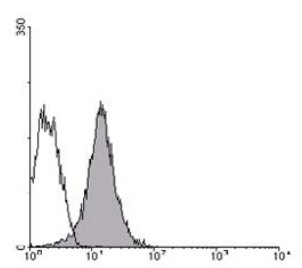

MHC-I

\section{Figure 4}

Expression of HPV-I6 E6 and E7 antigens in retrovirus-transduced ID8 cells. (A) RT-PCR analysis for HPV-I6 E6 and E7 transcripts in ID8 cells transduced with HPV-I6 E6 and E7 genes; ID8 cells transduced with empty vector (negative control); and TC-I cells (positive control). M: molecular markers. (B) Real-time quantitative PCR analysis of E6 and E7 transcripts in ID8 cells transduced with HPV-I6 E6 and E7 genes and ID8 cells carrying empty vector. (C) Western blot analysis of cell lysate showing presence of $\mathrm{E} 6$ protein in samples obtained from ID8 E6/7 cells but not in ID8 cells carrying empty vector. M: molecular markers. (D) Flow cytometry analysis of intracellular E6 and E7 proteins in ID8 cells transduced with HPV-I6 E6 and E7 genes. (grey): ID8 E6/7 cells; (white): ID8 cells transduced with empty vector, (dotted line): isotype control. (E) Expression of MHC-I by ID8-E6/7 cells. (grey): ID8 E6/7 cells; (white): isotype control. 
compared to ID8 cells transduced with the empty vector (ID8) (Figure 4A and 4B). Immunoprecipitation followed by Western blot analysis revealed the presence of E6 protein in ID8-E6/7 cells but not in ID8 cells transduced with empty vector (Figure 4C). Moreover, intracellular staining of ID8 E6/7 cells showed the presence of HPV-16 E6 and E7 proteins (Figure 4D). As the parental ID8 cell line [36], ID8-E6/7 cell line expressed MHC class-I molecules (Figure $4 \mathrm{E})$.

\section{RNA-DCs and UV-DCs are immunogenic in vivo}

We compared the efficacy of RNA-DCs and UV-DCs to induce tumor vaccination. To minimize differences in the amount of tumor antigen between pulsing procedures, DCs were incubated with UV-irradiated cells at 1:2 ratio (DC, tumor cell) or electroporated with an amount of total RNA equivalent to two tumor cells per DC, as above. DCs were matured with TNF- $\alpha$ and LPS. Mock DCs were prepared by electroporation in the absence of tumor RNA followed by maturation with TNF- $\alpha$ and LPS. Healthy animals were vaccinated with RNA-DCs or UV-DCs, while control animals were vaccinated with mock DCs or left unvaccinated (naïve). Splenocytes isolated from the above animals were tested for reactivity against E6 and E7 antigens by incubating them with apoptotic TC-1, ID8E6/7, ID8 or L-929 cells.

When incubated with TC-1 cells, splenocytes from animals vaccinated with RNA-DCs proliferated significantly more than splenocytes from animals vaccinated with UVDCs (Figure 5A). No proliferation was detected in lymphocytes from animals vaccinated with mock-electroporated DCs or naïve animals (Figure 5A). Similar proliferation was detected when splenocytes from mice vaccinated with RNA-DCs were incubated with TC-1 or ID8-E6/7 cells (Figure 5B), but no proliferation was detected against control ID8 cells lacking E6 or E7, or L929 cells. This shows that the presence of HPV antigens was critical for $\mathrm{T}$ cell proliferation (Figure 5B). Splenocytes from all four groups of animals showed similar proliferative response when stimulated with phytohemagglutinin (not shown), indicating no functional impairment.

We evaluated the frequency of tumor-reactive $\mathrm{T}$ cells among splenocytes in each group of animals by IFN- $\gamma$ ELISPOT analysis. We used ID8-E6/E7 cells as target cells. A significantly higher frequency of tumor-reactive IFN- $\gamma$ producing cells was found in spleens from animals vaccinated with RNA-DCs compared to animals vaccinated with UV-DCs. No response was observed in splenocytes from mock vaccinated or naïve animals (Figure 5C). Similar response was seen in splenocytes from mice vaccinated with RNA-DCs incubated with TC-1 or ID8-E6/7 cells, while no response was observed against ID8 pr L-
929 cells (Figure 5D). Moreover, in the RNA vaccinated group, IFN- $\gamma$ producing cells were mainly $\mathrm{CD} 8^{+}$cells, since immunodepletion of $\mathrm{CD}^{+}$cells in vivo decreased the number of IFN- $\gamma$ producing cells among isolated splenocytes (Figure 5E).

Higher levels of cytotoxic lymphocyte activity were detected in lymphocytes obtained from animals vaccinated with RNA-DCs relative to the UV-DCs group (Figure 5F). Moreover, CTL activity of splenocytes was abrogated to control levels by immunodepletion of $\mathrm{CD}^{+}$cells in vivo (Figure 5F). No lytic activity was observed when control ID8 cells expressing no E6 or E7, or L-929 cells were used as target cells, confirming the specificity of the reaction (not shown).

TC-1 tumors express HPV E6 and E7, offering the opportunity to quantify $\mathrm{T}$ cell responses against tumor-associated HPV epitopes through well-characterized tetramers [37]. We compared the ability of RNA-DCs and UV-DCs to generate $\mathrm{T}$ cell response against the $\mathrm{H} 2-\mathrm{D}^{\mathrm{b}}$-restricted HPV E7 epitope RAHYNIVTF [34]. A four-fold higher frequency of tetramer-positive $\mathrm{CD} 3{ }^{+} \mathrm{CD} 8{ }^{+}$cells was detected in splenocytes from animals vaccinated with RNA-DCs compared to animals vaccinated with UV-DCs (Figure $5 G)$.

\section{Vaccination with RNA-DCs or UV-DCs}

To test the efficacy of RNA-DCs and UV-DCs in vivo, healthy mice were vaccinated with three injections of RNA-DCs or UV-DCs prepared as above and administered one week apart. Seven days after the last DC vaccination, animals were challenged with flank subcutaneous TC-1 tumors. Tumor growth was significantly delayed in animals vaccinated with RNA-DCs as well as animals vaccinated with UV-DCs (Figure 6A). Although the difference in tumor growth between mice vaccinated with RNA-DCs and mice vaccinated with UV-DCs was not large, tumors were significantly smaller in mice vaccinated with RNADCs. Similar results were obtained in three independent experiments.

Tumors from mice vaccinated with RNA-DCs as well as from animals vaccinated with UV-DCs exhibited significantly higher frequency of $\mathrm{CD}^{+}$tumor-infiltrating cells relative to mice vaccinated with mock DCs. A higher frequency of $\mathrm{CD}^{+}+$tumor-infiltrating cells was detected in animals vaccinated with RNA-DCs compared to animals vaccinated with UV-DCs (Figure 6B, C). Finally, a higher proportion of $\mathrm{CD}^{+}$cells were $\mathrm{CD} 8+$ in animals vaccinated with RNA-DCs compared to animals vaccinated with UVDCs or mock DCs (Figure 6D). 
SPLENOCYTE PROLIFERATION

A

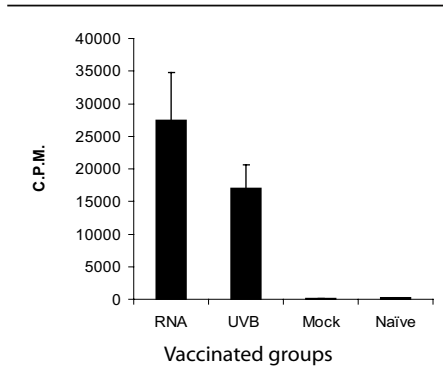

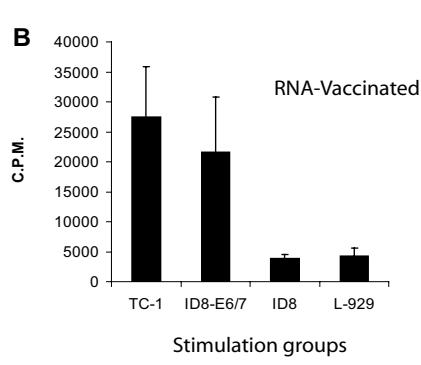

IFN-gamma ELISPOT
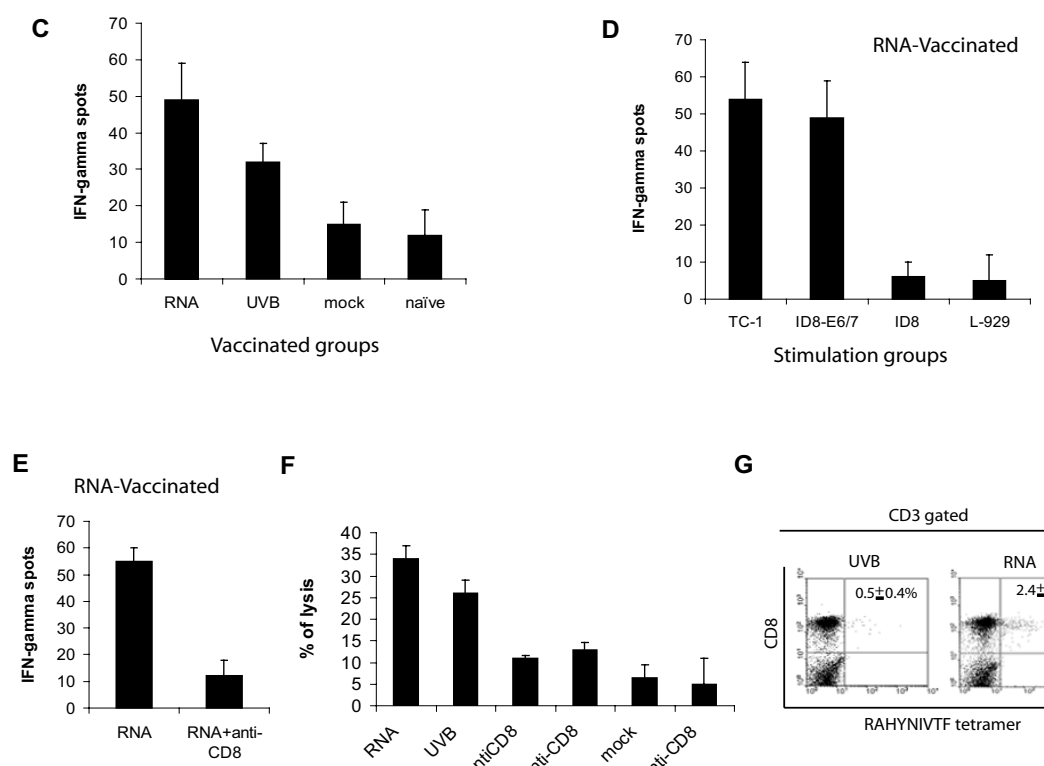

$\mathbf{F}$

G
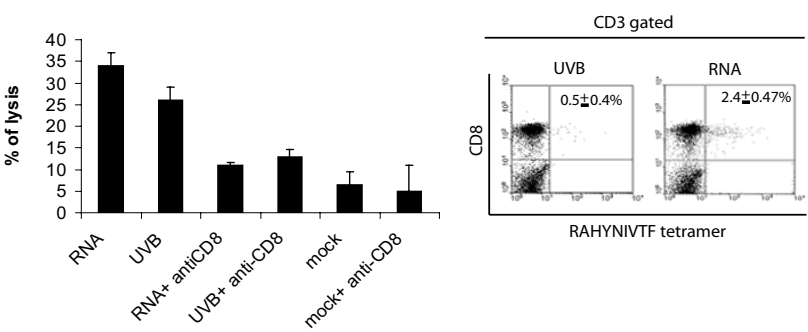

Figure 5

Antitumor immune response in vaccinated animals. (A) Proliferation of splenocytes from animals vaccinated with DCs electroporated with TC-I RNA (RNA); pulsed with UV-irradiated TC-I cells (UVB); mock-electroporated DCs (mock), or naïve animals. Splenocytes were stimulated in vitro with gamma-irradiated TC-I cells for 5 days. Data are expressed as the mean \pm SD $(n=5)$. RNA vs. UVB: $p<0.0$ I; RNA vs. mock: $p<0.00$ I; RNA vs. naive: $p<0.00$; UVB vs. mock: $p<0.00$ I; UVB vs. naive: $p$ $<0.001$ (ANOVA, Tukey-Kramer multicomparison post-test). (B) Proliferation of splenocytes from animals vaccinated with DCs electroporated with TC-I cell RNA. Splenocytes were stimulated in vitro for 5 days with gamma-irradiated TC-I cells, ID8-E6/E7 cells, ID8 cells carrying empty vector or L-929 cells. Data are expressed as the mean \pm SD ( $n=5)$. TC-I vs. ID8-E6/ 7: non significant (NS); TC-I vs. ID8: $p<0.00$; TC-I vs. L-929: $p<0.001$; ID8-E6/7 vs. ID8: $p<0.00$ I; ID8-E6/7 vs. L-929: $p<$ 0.001 . The experiment was repeated two times with similar results. (C) Quantification of IFN- $\gamma$ producing tumor-reactive splenocytes by ELISPOT from the same experimental groups as in A. Data are expressed as the mean \pm SD ( $n=5$ ). RNA vs. UVB: $p<0.05$; RNA vs. mock: $p<0.005$; RNA vs. naive: $p<0.005$; UVB vs. mock: $p<0.005$; UVB vs. naive: $p<0.005$. (D) Quantification of IFN- $\gamma$ producing tumor-reactive splenocytes by ELISPOT from the same experimental groups as in B. Data are expressed as the mean \pm SD $(n=5)$. TC-I vs. ID8-E6/7: non significant (NS); TC-I vs. ID8: $p<0.00$ I; TC-I vs. L-929: $p<$ 0.00I; ID8-E6/7 vs. ID8: $p<0.00$ I; ID8-E6/7 vs. L-929: $p<0.00$ I. (E) IFN- $\gamma$ producing cells from splenocytes of RNA vaccinated animals upon CD8 immunodepletion. $p<0.0$ I. (F) Cytotoxic assay using TC-I cells as targets. Tumor cells were incubated at 3:I effector:target ratio with gradient-purified pooled splenic lymphocytes from animals vaccinated with DCs electroporated with TC-I cell RNA (RNA) or pulsed with UV-irradiated TC-I cells (UVB). Some groups were immunodepleted of $C D 8^{+}$cells. Splenocytes were stimulated in vitro with gamma-irradiated TC-I cells for 5 days. RNA vs. UVB: $P<0.05$; Student's t-test. The experiment was repeated two times with similar results. (G) Frequency of anti-E7 CD8 ${ }^{+}$lymphocytes following DC vaccination. E7 tetramer-positive, CD3-gated $C D 8^{+}$precursors were quantified in splenocytes from animals vaccinated with DCs pulsed with UVB-irradiated TC-I cells (UVB) or DCs electroporated with TC-I cell RNA (RNA), P < 0.05 . 
A

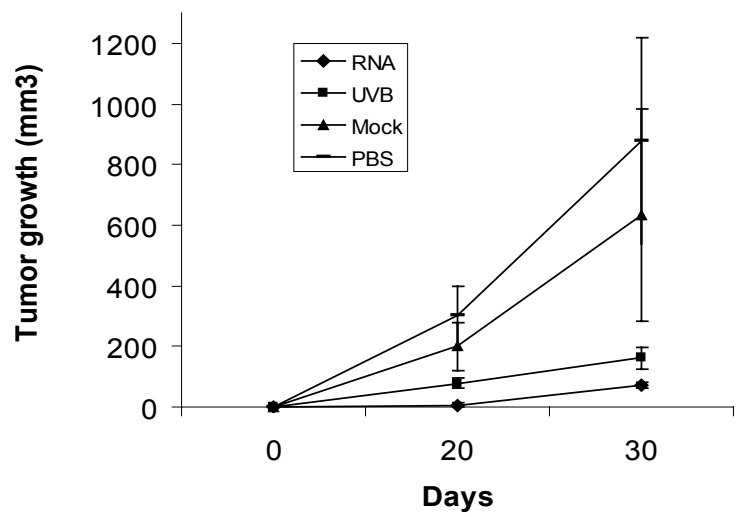

B

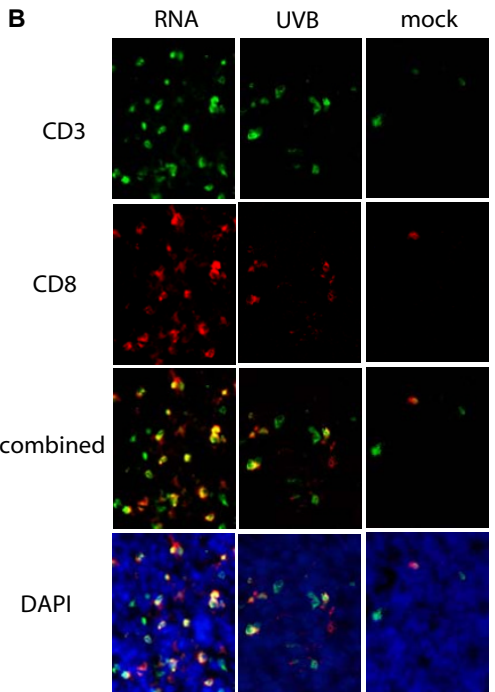

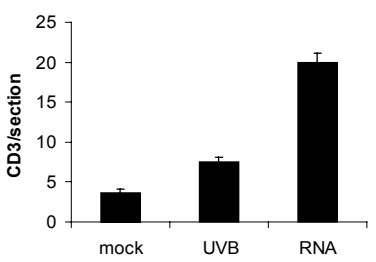

D

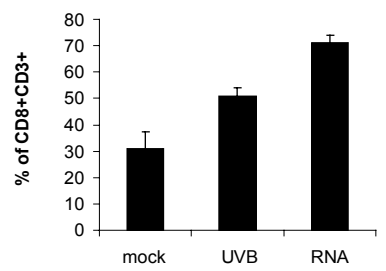

\section{Figure 6}

Antitumor efficacy of RNA electroporated DCs. (A) Growth of flank TC-I tumors in animals previously vaccinated with DCs electroporated with TC-I cell RNA, UV-irradiated TC-I cells, mock DCs or non-treated. Animals were challenged by injecting $2 \times 10^{4}$ tumor cells. ( $n=5$ each group). Data are representative of three independent experiments with similar results. Day 30 : RNA vs. UVB: $p<0.01$; RNA vs. PBS: $p<0.01$; RNA vs mock: $p<0.01$; UVB vs. PBS: $p<0.01$; UVB vs. mock: $p<0.01$; PBS vs. mock: non significant. Mann-Whitney test. (B) CD3 and CD8 staining of tumors obtained from animals vaccinated with DCs electroporated with TC-I cell RNA (RNA), DCs pulsed with UVB-irradiated TC-I cells (UVB), or mock electroporated DCs. Magnification: 200X. (C) Counting of CD3 cells infiltrating TC-I tumors. Experimental groups as in A. RNA vs. UVB: $P$ < 0.00 I; RNA vs. mock: $p<0.001$; UVB vs. mock: $p<0.001$. Kruskal-Wallis non parametric ANOVA test. Dunn's multiple comparisons test. (D) Percentage of $C D 8^{+}$among $C D 3^{+}$cells infiltrating TC-I tumors. Experimental groups as in A. RNA vs. UVB: $P<0.05$; RNA vs. mock: $p<0.00 I$; UVB vs. mock: NS (Kruskal-Wallis non parametric ANOVA test. Dunn's multiple comparisons test). 


\section{Discussion}

The present work addressed the relative efficacy of tumor vaccines prepared with DCs either electroporated with tumor RNA or with dead tumor cells. We used total RNA from tumor cells isolated with a common laboratory method and UVB irradiated tumor cells and optimized the conditions to minimize difference in amount of tumor cell material used to pulse DCs. We used the E7 MHC-I-restricted epitope RAHYNIVTF to quantify the intensity of CD8 ${ }^{+} \mathrm{T}$ cell response against tumor-associated antigens. The present results show that electroporation with whole tumor cell RNA and pulsing with UVB-irradiated tumor cells are both effective in eliciting antitumor immune response, but RNA electroporation results in more potent tumor vaccination. The efficacy of the vaccination by RNA-electroporated DCs was dependent on the presence of $\mathrm{CD}^{+}$cells, since in vivo depletion of these cells abrogated the reported effect. Importantly, vaccination with RNA-electroporated DCs expressing E6 and E7 significantly enhanced infiltration of $\mathrm{CD} 3{ }^{+} \mathrm{CD} 8+$ into the tumors.

To our knowledge this is the first direct comparison between irradiated cells and whole RNA as a source of whole tumor antigen to prepare DC based tumor vaccines. Because the same number of cells was used to derive tumor antigen with both methodologies, the above findings indicate that RNA electroporation is an efficient methodology for loading DCs with tumor antigen. A previous report also found that apoptotic tumor cell pulsing is not an efficient approach to tumor vaccination [38]. Several reasons may account for our findings. First, antigen up-take may be less efficient with pulsing dying cells compared to RNA electroporation. Since UVB irradiation has been shown to result in a mixed population of apoptotic and necrotic tumor cells [16], it is possible that either process leads to degradation of important antigens [39], resulting in suboptimal antigen processing or presentation. Second, apoptotic DNA may bind to MHC class molecules and interfere with antigen presentation [40]. Third, although non-viral methods of DNA transfection of DCs are inefficient, the efficiency of gene transfer with RNA electroporation resembles that of transfection with recombinant viruses [41]. Finally, another advantage of RNA transfer of DC over pulsing DC with protein antigens is that endogenously synthesized antigens have better access to the class I MHC pathway [42].

It is noteworthy to comment that different maturation protocols can modify the capability of DCs to effectively present antigens upon RNA electroporation. In a series of elegant studies, Zobylawski et al., have shown that human DCs treated with a maturation cocktail formulated with TNF, IL-1 $\beta$, IFN- $\gamma$, prostaglandin E2, and the Toll like receptor (TLR) 8 agonist R848 were able to generate an efficient immune response upon RNA electroporation; while addition of the TLR3 ligand poly(I:C) to the maturation cocktail rendered DCs unable to express proteins from electroporated RNA [43]. Indeed, the formulation of appropriate maturation cocktails is one of the challenges that faces the generation of effective DC-based vaccines for clinical use [44]. Thus, the use of different activation protocols might have produced different results in our studies. Further, since in our studies we used murine bone marrow-derived DCs, they may not directly translate to human monocyte-derived dendritic cells used for clinical studies. Additional studies with human monocytederived dendritic cells must be performed in order to determine the clinical relevance of our findings. Finally, it should be noted that our work compared RNA to dead tumor cells and our findings on superiority of RNA as a source of whole tumor antigen may not be relevant to alternate methods of preparing whole tumor cell protein, such as tumor lysates [45], which may preserve tumor antigens or do not interfere with antigen presentation.

\section{Conclusion}

Collectively, our data suggest that electroporation of whole tumor RNA represents a direct and effective way of delivering tumor antigen to DCs ex vivo. Coupled with the easier procurement of tumor RNA compared to the generation of tumor cell lines, these findings suggest that RNA electroporation should be a preferred method of loading DCs with whole tumor antigen in clinical trials.

\section{Abbreviations}

DCs: dendritic cells; DEPC: diethylpyrocarbonate; FACS: fluorescence activated cell sorting; GM-CSF: granulocyte macrophage-colony stimulation factor; HPV: human papilloma virus; IFN: interferon; LPS: lipopolysaccharide; MHC: major histocompatibility complex; MIP: macrophage inflammatory protein; PBS: phosphate buffered saline; RNA: ribonucleic acid; RPMI: Rosewell Park Memorial Institute - cell culture medium; TLR: Toll-like receptor; TNF: tumor necrosis factor; UVB: ultraviolet-B

\section{Competing interests}

The authors declare that they have no competing interests.

\section{Authors' contributions}

FB participated in study design, carried out the in vitro and in vivo studies and drafted the manuscript and figures. MCC assisted with all the in vitro and in vivo experiments. GC conceived of the study, participated in its design and coordination, and finalized the manuscript.

\section{Acknowledgements}

This study was supported by NCI POI-CA83638 SPORE in Ovarian Cancer; the Cooperative Ovarian Cancer Group for Immunotherapy (COGI) grant by the Ovarian Cancer Research Fund (OCRF); and the National Ovarian Cancer Coalition. 


\section{References}

I. Hsueh EC: Tumour cell-based vaccines for the treatment of melanoma. BioDrugs 200 I, I 5(I I):7 I3-720.

2. Scanlan MJ, Jager D: Challenges to the development of antigenspecific breast cancer vaccines. Breast Cancer Res 200I, 3(2):95-98.

3. Chen W, Wang J, Shao C, Liu S, Yu Y, Wang Q, Cao X: Efficient induction of antitumor $\mathrm{T}$ cell immunity by exosomes derived from heat-shocked lymphoma cells. European journal of immunology 2006, 36(6): 1598-1607.

4. Chen Z, Moyana T, Saxena A, Warrington R, Jia Z, Xiang J: Efficient antitumor immunity derived from maturation of dendritic cells that had phagocytosed apoptotic/necrotic tumor cells. International journal of cancer 200I, 93(4):539-548.

5. Henry F, Boisteau O, Bretaudeau L, Lieubeau B, Meflah K, Gregoire $M$ : Antigen-presenting cells that phagocytose apoptotic tumor-derived cells are potent tumor vaccines. Cancer research 1999, 59(14):3329-3332.

6. Hoffmann TK, Meidenbauer N, Dworacki G, Kanaya H, Whiteside TL: Generation of tumor-specific T-lymphocytes by cross-priming with human dendritic cells ingesting apoptotic tumor cells. Cancer research 2000, 60( I 3):3542-3549.

7. Russo V, Tanzarella S, Dalerba P, Rigatti D, Rovere P, Villa A, Bordignon C, Traversari C: Dendritic cells acquire the MAGE-3 human tumor antigen from apoptotic cells and induce a class I-restricted T cell response. Proceedings of the National Academy of Sciences of the United States of America 2000, 97(5):2 I 85-21 90.

8. Shaif-Muthana M, Mclntyre C, Sisley K, Rennie I, Murray A: Dead or alive: immunogenicity of human melanoma cells when presented by dendritic cells. Cancer research 2000, 60(22):644I-6447.

9. Schnurr M, Scholz C, Rothenfusser S, Galambos P, Dauer M, Robe J, Endres S, Eigler A: Apoptotic pancreatic tumor cells are superior to cell lysates in promoting cross-priming of cytotoxic $\mathbf{T}$ cells and activate NK and gammadelta T cells. Cancer research 2002, 62(8):2347-2352.

10. Scheffer SR, Nave H, Korangy F, Schlote K, Pabst R, Jaffee EM, Manns $M P$, Greten TF: Apoptotic, but not necrotic, tumor cell vaccines induce a potent immune response in vivo. International journal of cancer 2003, I 03(2):205-2II.

II. von Euw EM, Barrio MM, Furman D, Levy EM, Bianchini M, Peguillet I, Lantz O, Vellice A, Kohan A, Chacon M, Yee C, Wainstok R, Mordoh $\mathrm{J}$ : A phase I clinical study of vaccination of melanoma patients with dendritic cells loaded with allogeneic apoptoticl necrotic melanoma cells. Analysis of toxicity and immune response to the vaccine and of IL-I 0 - 1082 promoter genotype as predictor of disease progression. J Transl Med 2008, 6(I):6.

12. von Euw EM, Barrio MM, Furman D, Bianchini M, Levy EM, Yee C, Li $Y$, Wainstok R, Mordoh J: Monocyte-derived dendritic cells loaded with a mixture of apoptotic/necrotic melanoma cells efficiently cross-present gp I 00 and MART-I antigens to specific CD8+ T lymphocytes. J Transl Med 2007, 5: 19.

13. Gallucci S, Lolkema M, Matzinger P: Natural adjuvants: endogenous activators of dendritic cells. Nature medicine 1999, 5(I I): I249-I255.

14. Basu S, Binder RJ, Suto R, Anderson KM, Srivastava PK: Necrotic but not apoptotic cell death releases heat shock proteins, which deliver a partial maturation signal to dendritic cells and activate the NF-kappa B pathway. International immunology 2000, I 2(I I): I 539- I546.

15. Sauter B, Albert ML, Francisco L, Larsson M, Somersan S, Bhardwaj $N$ : Consequences of cell death: exposure to necrotic tumor cells, but not primary tissue cells or apoptotic cells, induces the maturation of immunostimulatory dendritic cells. The Journal of experimental medicine 2000, 191 (3):423-434.

16. Kotera $Y$, Shimizu K, Mule JJ: Comparative analysis of necrotic and apoptotic tumor cells as a source of antigen(s) in dendritic cell-based immunization. Cancer research 2001, 6 I (22):8I05-8I09.

17. Schlienger K, Chu CS, Woo EY, Rivers PM, Toll AJ, Hudson B, Maus MV, Riley JL, Choi Y, Coukos G, Kaiser LR, Rubin SC, Levine BL, Carroll RG, June CH: TRANCE- and CD40 ligand-matured dendritic cells reveal MHC class I-restricted T cells specific for autologous tumor in late-stage ovarian cancer patients. Clin Cancer Res 2003, 9(4): 1517-1527.
18. Boczkowski D, Nair SK, Snyder D, Gilboa E: Dendritic cells pulsed with RNA are potent antigen-presenting cells in vitro and in vivo. The Journal of experimental medicine 1996, I 84(2):465-472.

19. Ashley DM, Faiola B, Nair S, Hale LP, Bigner DD, Gilboa E: Bone marrow-generated dendritic cells pulsed with tumor extracts or tumor RNA induce antitumor immunity against central nervous system tumors. The Journal of experimental medicine 1997, I86(7): I I77-I I82.

20. Nair SK, Morse M, Boczkowski D, Cumming RI, Vasovic L, Gilboa E, Lyerly HK: Induction of tumor-specific cytotoxic T lymphocytes in cancer patients by autologous tumor RNAtransfected dendritic cells. Annals of surgery 2002 , 235(4):540-549.

21. Ponsaerts P, Van den Bosch G, Cools N, Van Driessche A, Nijs G, Lenjou M, Lardon F, Van Broeckhoven C, Van Bockstaele DR, Berneman ZN, Van Tendeloo VF: Messenger RNA electroporation of human monocytes, followed by rapid in vitro differentiation, leads to highly stimulatory antigen-loaded mature dendritic cells. J Immunol 2002, I 69(4): I669-I675.

22. Geiger C, Regn S, Weinzierl A, Noessner E, Schendel DJ: A generic RNA-pulsed dendritic cell vaccine strategy for renal cell carcinoma. J Transl Med 2005, 3:29.

23. Markovic SN, Dietz AB, Greiner CW, Maas ML, Butler GW, Padley DJ, Bulur PA, Allred JB, Creagan ET, Ingle JN, Gastineau DA, Vuk-Pavlovic S: Preparing clinical-grade myeloid dendritic cells by electroporation-mediated transfection of in vitro amplified tumor-derived mRNA and safety testing in stage IV malignant melanoma. J Transl Med 2006, 4:35.

24. Roby KF, Taylor CC, Sweetwood JP, Cheng Y, Pace JL, Tawfik O, Persons DL, Smith PG, Terranova PF: Development of a syngeneic mouse model for events related to ovarian cancer. Carcinogenesis 2000, 2 I (4):585-59l.

25. Halbert CL, Demers GW, Galloway DA: The E7 gene of human papillomavirus type 16 is sufficient for immortalization of human epithelial cells. Journal of virology I991, 65(I):473-478.

26. Lutz MB, Kukutsch N, Ogilvie AL, Rossner S, Koch F, Romani N, Schuler G: An advanced culture method for generating large quantities of highly pure dendritic cells from mouse bone marrow. J Immunol Methods 1999, 223(I):77-92.

27. Pan ZK, Ikonomidis G, Lazenby A, Pardoll D, Paterson Y: A recombinant Listeria monocytogenes vaccine expressing a model tumour antigen protects mice against lethal tumour cell challenge and causes regression of established tumours. Nature medicine 1995, I(5):47|-477.

28. Courreges MC, Benencia F, Conejo-Garcia JR, Zhang L, Coukos G: Preparation of apoptotic tumor cells with replication-incompetent HSV augments the efficacy of dendritic cell vaccines. Cancer gene therapy 2006, I3(2): 182-193.

29. Ogata M, Zhang Y, Wang Y, Itakura M, Zhang YY, Harada A, Hashimoto $S$, Matsushima K: Chemotactic response toward chemokines and its regulation by transforming growth factor-betal of murine bone marrow hematopoietic progenitor cellderived different subset of dendritic cells. Blood 1999 , 93(10):3225-3232.

30. Conejo-Garcia JR, Benencia F, Courreges MC, Khang E, Zhang L, Mohamed-Hadley A, Vinocur JM, Buckanovich RJ, Thompson CB, Levine B, Coukos G: Letal, A tumor-associated NKG2D immunoreceptor ligand, induces activation and expansion of effector immune cells. Cancer Biol Ther 2003, 2(4):446-45I.

31. Lin KY, Guarnieri FG, Staveley-O'Carroll KF, Levitsky HI, August JT, Pardoll DM, Wu TC: Treatment of established tumors with a novel vaccine that enhances major histocompatibility class II presentation of tumor antigen. Cancer research 1996, 56(I):2I-26.

32. Gunn GR, Zubair A, Peters C, Pan ZK, Wu TC, Paterson Y: Two Listeria monocytogenes vaccine vectors that express different molecular forms of human papilloma virus-I6 (HPV-16) E7 induce qualitatively different $T$ cell immunity that correlates with their ability to induce regression of established tumors immortalized by HPV-I 6. J Immunol 200 I, I 67( I I):647I-6479.

33. Hussain SF, Paterson Y: CD4+CD25+ regulatory $T$ cells that secrete TGFbeta and IL- 10 are preferentially induced by $a$ vaccine vector. J Immunother 2004, 27(5):339-346.

34. Lamikanra A, Pan ZK, Isaacs SN, Wu TC, Paterson Y: Regression of established human papillomavirus type 16 (HPV-I6) immortalized tumors in vivo by vaccinia viruses expressing differ- 
ent forms of HPV-16 E7 correlates with enhanced CD8(+) Tcell responses that home to the tumor site. Journal of virology 200I, 75(20):9654-9664.

35. Sallusto F, Kremmer E, Palermo B, Hoy A, Ponath P, Qin S, Forster R, Lipp M, Lanzavecchia A: Switch in chemokine receptor expression upon TCR stimulation reveals novel homing potential for recently activated T cells. European journal of immunology 1999, 29(6):2037-2045.

36. Zhang L, Yang N, Garcia JR, Mohamed A, Benencia F, Rubin SC, Allman D, Coukos G: Generation of a syngeneic mouse model to study the effects of vascular endothelial growth factor in ovarian carcinoma. Am J Pathol 2002, I6 I(6):2295-2309.

37. Ji H, Chang EY, Lin KY, Kurman RJ, Pardoll DM, Wu TC: Antigenspecific immunotherapy for murine lung metastatic tumors expressing human papillomavirus type 16 E7 oncoprotein. International journal of cancer 1998, 78(I):4I-45.

38. Galea-Lauri J, Darling D, Mufti G, Harrison P, Farzaneh F: Eliciting cytotoxic $T$ lymphocytes against acute myeloid leukemiaderived antigens: evaluation of dendritic cell-leukemia cell hybrids and other antigen-loading strategies for dendritic cell-based vaccination. Cancer Immunol Immunother 2002, 5I(6):299-3I0.

39. Labarriere N, Bretaudeau L, Gervois N, Bodinier M, Bougras G, Diez E, Lang F, Gregoire M, Jotereau F: Apoptotic body-loaded dendritic cells efficiently cross-prime cytotoxic $T$ lymphocytes specific for NAI7-A antigen but not for Melan-A/MART-I antigen. International journal of cancer 2002, I 0 I (3):280-286.

40. Filaci G, Contini P, Fravega M, Fenoglio D, Azzarone B, Julien-Giron M, Fiocca R, Boggio M, Necchi V, De Lerma Barbaro A, Merlo A, Rizzi M, Ghio M, Setti M, Puppo F, Zanetti M, Indiveri F: Apoptotic DNA binds to HLA class II molecules inhibiting antigen presentation and participating in the development of anti-inflammatory functional behavior of phagocytic macrophages. Human immunology 2003, 64(I):9-20.

4I. Kim CJ, Prevette T, Cormier J, Overwijk W, Roden M, Restifo NP, Rosenberg SA, Marincola FM: Dendritic cells infected with poxviruses encoding MART-I/Melan A sensitize T lymphocytes in vitro. J Immunother (1997) 1997, 20(4):276-286.

42. Rea D, Johnson ME, Havenga MJ, Melief C), Offringa R: Strategies for improved antigen delivery into dendritic cells. Trends in molecular medicine 200I, 7(3):9I-94.

43. Zobywalski A, Javorovic M, Frankenberger B, Pohla $\mathrm{H}$, Kremmer $\mathrm{E}$, Bigalke I, Schendel DJ: Generation of clinical grade dendritic cells with capacity to produce biologically active IL-12p70. J Transl Med 2007, 5: 18.

44. Gilboa E: DC-based cancer vaccines. The Journal of clinical investigation 2007, II7(5): I I95-I203.

45. Ridolfi R, Petrini M, Fiammenghi L, Stefanelli M, Ridolfi L, Ballardini M, Migliori G, Riccobon A: Improved overall survival in dendritic cell vaccination-induced immunoreactive subgroup of advanced melanoma patients. J Transl Med 2006, 4:36.

\section{Publish with Bio Med Central and every scientist can read your work free of charge}

"BioMed Central will be the most significant development for disseminating the results of biomedical research in our lifetime. "

Sir Paul Nurse, Cancer Research UK

Your research papers will be:

- available free of charge to the entire biomedical community

- peer reviewed and published immediately upon acceptance

- cited in PubMed and archived on PubMed Central

- yours - you keep the copyright

Submit your manuscript here:

http://www.biomedcentral.com/info/publishing_adv.asp
BioMedcentral 